\title{
Accumulation of Chlorophyll and Essential Oils in Photomixotrophic Cell Cultures of Citrus sp.
}

Gerold Reil ${ }^{\mathrm{a}}$ and Ralf Günter Berger ${ }^{\mathrm{b}}$

${ }^{a}$ Institut für Lebensmitteltechnologie und Analytische Chemie der Technischen Universität München, D-85350 Freising, Bundesrepublik Deutschland

b Institut für Lebensmittelchemie der Universität Hannover, D-30453 Hannover, Bundesrepublik Deutschland

Z. Naturforsch. 51c, 657-666 (1996); received March 12/June 18, 1996

Citrus, Cell Culture, Photomixotrophy, Oligoprenoids, Limonene

Heterotrophically or photomixotrophically initiated callus cultures of Citrus paradisi, C. limon and C.aurantifolia were grown on different nutrient media and under different light regimes. Calli of C.paradisi that contained $>140 \mathrm{mg}$ chlorophyll per $\mathrm{kg}$ wet weight accumulated about 40 volatile mono- and sesquiterpene hydrocarbons, oxigenated terpenes and aliphatic aldehydes. Upon five subcultivations the best yielding callus contained about 5\% (186 $\mathrm{mg} \times \mathrm{kg}^{-1}$ wet $\mathrm{wt}$ ) of the volatiles found in peel tissue (exo/mesocarp section), and about the twentyfold amount of that found in the fleshy endocarp. The composition of the essential oils from most of the cell cultures equalled grapefruit peel oil, but was shifted to a more fruit flesh-like composition, after the concentration of gellan gum in the medium was increased from 3 to $9 \mathrm{~g}$ per $\mathrm{L}$. C. limon produced 11 monoterpenes and n-nonanal $\left(40 \mathrm{mg} \times \mathrm{kg}^{-1}\right.$ wet wt max.), and C.aurantifolia yielded limonene only $\left(4.4 \mathrm{mg} \times \mathrm{kg}^{-1}\right.$ wet wt max.). For all of the indicated species chlorophyll content and accumulation of volatiles were positively correlated. Addition of exogenous valencene to suspended cells of C.paradisi led to a stable concentration of the conversion product nootkatone. This stably maintained level suggested that a decreased catabolism of available carbon sources might have accounted for the significant accumulation of essential oil constituents.

\section{Introduction}

In view of the wide usage of Citrus species in the food, pharmaceutical and cosmetic industries, it is not surprising that cell cultures were established to investigate somatic embryogenesis and hybridization, micropropagation, gene transfer and flavonoid formation (Del Rio and Ortuño, 1994). Volatile constituents have received less attention, as it was shown that Citrus cultures, like most other cell cultures derived from essential oil plants, do not accumulate anything like significant levels (Bricout and Paupardin, 1974; Paupardin, 1974; Drawert and Berger, 1982).

More recently, dark grown callus cultures of various Citrus species were reported to produce valencene and nootkatone ( 0.1 and $1.6 \mathrm{mg} \times \mathrm{kg}^{-1}$ wet wt max., respectively) when grown on a $10 \%$ orange juice medium (Del Rio and Ortuño, 1994). The maximum values for valencene were found in

Reprint requests to R. G. Berger. Telefax: 0511/762-4547. young calli, whereas nootkatone accumulation started in older calli and was accompanied by the generation of lysigenous intercellular spaces. Calli of C.aurantifolia S. produced a total of $2.8 \mathrm{~g}$ volatile oxygenated terpenes $\times \mathrm{kg}^{-1}$ wet weight, when grown on an optimized medium under a $12 \mathrm{~h}$ photoperiod (Agrawal et al., 1991). These authors successfully used the central composite rotatory design, a statistical tool for the rapid optimization of the growth medium, to improve the chemical environment of the cultured cells and identified citral, terpinyl and amyl acetate, dodecanal and a sesquiterpene alcohol as the volatile constituents. No attempts have ever been made to quantify the effect of light on the synthesis of volatile metabolites in Citrus cell cultures.

\section{Materials and Methods}

\section{Cell cultures}

Citrus paradisi Macf. cv. White Marsh, C. limon (L.) Burm.f. and C.aurantifolia Swingle fruits were from the local market. Intact, mature fruits were 
surface sterilized with $70 \%$ ethanol (one min), followed by $2 \% \mathrm{w} / \mathrm{v} \mathrm{Ca}(\mathrm{OCl})_{2}$ solution for $10 \mathrm{~min}$ and then rinsed three times with sterile water. Callus was initiated using excised flavedo and MS (Murashige and Skoog, 1962) and a modified MS medium (MSL), as applied by Agrawal et al. (1991) for the production of terpenes. This medium differed from the known MS medium in these constituents: $\mathrm{KNO}_{3} 1245 \mathrm{mg} \cdot \mathrm{l}^{-1}, \mathrm{KH}_{2} \mathrm{PO}_{4}$ $1500 \mathrm{mg} \cdot \mathrm{l}^{-1}$, and phytoeffectors (Sigma) as indicated in the text. The solidifier was $3 \mathrm{~g}$ of gellan gum (Kelco) per 1 for each medium. The calli initiated on MSL grew only slowly when subcultured on other media. The SH4 variant, developed during an earlier study (Berger et al., 1990), differed from the original SH medium (Schenk and Hildebrandt, 1972) in the contents of sucrose $\left(10 \mathrm{~g} \cdot \mathrm{l}^{-1}\right)$, lactose $\times \mathrm{H}_{2} \mathrm{O}\left(10 \mathrm{~g} \cdot \mathrm{l}^{-1}\right)$, kinetin $\left(2 \mathrm{mg} \cdot \mathrm{l}^{-1}\right)$, and $p$ chlorophenoxyacetic acid (none). The explants and all subcultures were maintained under continuous light of a $\mathrm{Hg}$-high pressure lamp (Osram $\left.\mathrm{HQL} / \mathrm{R} 80 \mathrm{~W}, 3000 \mathrm{~lx}=3000 \mathrm{~cd} \cdot \mathrm{sr} \cdot \mathrm{m}^{-2}\right)$, or under the light of a neon tube (colour 12 with $\lambda_{\max }=$ 435 and $545 \mathrm{~nm}$, Osram) and at $23{ }^{\circ} \mathrm{C}$.

For the sake of comparison, cells were cultured under or reconverted to heterotrophic conditions in the dark at $27{ }^{\circ} \mathrm{C}$. Suspended cells were kept under identical conditions at $140 \mathrm{rpm}$ in $300 \mathrm{ml}$ Erlenmeyer flasks. Inoculation density was $10 \mathrm{~g}$ filtered wet wt $100 \mathrm{ml}^{-1}$ medium.

Fully developed primary callus was transferred to cultivation conditions as indicated in Tables I and III, and analyzed immediately and after the fifth subcultivation cycle. In order to evaluate the effects of light colour, photoperiod, concentration of gelling agent and phytoeffectors on growth and accumulation of secondary products, one set of experimental combinations was designed for each of the species: The light colours and the gellan gum concentrations used did significantly stimulate chlorophyll formation in concurrent experiments with other members of the Rutaceae family (data not shown); phytoeffector concentrations were adopted from a previous study on Citrus (Agrawal et al., 1991) and a second variant with increased concentrations included. Callus cells were transferred to fresh medium every 2 to 7 weeks, and suspension cells every 3 weeks.

All chemicals used for preparation of nutrient media and chemical analysis were p.a. grade
(Merck); water was deionized and showed a conductivity of $<0.2 \mu \mathrm{S}$.

\section{Determination of chlorophyll, growth index and light intensity}

The sum of chlorophyll $a$ and $b$ was determined spectrophotometrically at $652 \mathrm{~nm}$ in a $80 \%(\mathrm{v} / \mathrm{v})$ acetone extract using $5 \mathrm{~g}$ wet wt. The ratio of chlorophyll $a / b$ was determined according to Ziegler and Egle (1965).

The growth index was calculated by comparing cell wet masses at harvest and at inoculation as $\left(\mathrm{M}_{\mathrm{h}}-\mathrm{M}_{\mathrm{i}}\right) / \mathrm{M}_{\mathrm{i}}$.

Light intensity was measured on surface cell level using a Metrux lux meter (Metrawatt) and a Data Logger LI-1000, I-COR with quantum sensor (PAR). $1 \mathrm{~lx}=1 \mathrm{~lm} \cdot \mathrm{m}^{2}, 1 \mathrm{~lm}=1$ candela . steradiant.

\section{Addition of valencene}

A single addition of valencene in ethanol (one $\mathrm{mL}$ of a stock solution $1 \mathrm{mmol} \cdot \mathrm{l}^{-1}$ to $150 \mathrm{ml}$ of medium) was made at the end of the linear growth phase. Purity (determined by GLC) was $>99.8 \%$.

\section{Preparation of the extracts for GLC analysis}

Extracts from the fruit parts of the plant and from callus or suspension cultures were prepared immediately after buying or harvesting of the plant material. Callus cells were carefully separated from adhering medium, mixed with the twofold amount per weight of $\mathrm{MeOH}$ and $1 \mathrm{ml}$ internal standard $\left(100 \mu \mathrm{g}\right.$ 2-undecanone $\left.\cdot \mathrm{ml}^{-1}\right)$ in a cooled Waring Blendor (30 s). The homogenate was centrifuged $\left(5000 \times \mathrm{g}, 10 \mathrm{~min},-4^{\circ} \mathrm{C}\right)$, and the supernatant was diluted with a saturated solution of $\mathrm{NaCl}$ to a $\mathrm{MeOH}$ concentration below $40 \%$. This solution was extracted three times with pentane/diethyl ether (2/1). The dried extract was concentrated at $40^{\circ} \mathrm{C}$ using a Vigreux column, and subjected to capillary gas chromatography or mass spectroscopy.

\section{Gas liquid chromatography and coupled mass spectrometry}

A $25 \mathrm{~m} \times 0.32 \mathrm{~mm}$ i.d. fused silica capillary column coated with SE 54, $1 \mu \mathrm{m}$ film thickness (Leupold, Weihenstephan) was used. Conditions: Tem- 
perature program $50{ }^{\circ} \mathrm{C}$ for $5 \mathrm{~min}$ isothermal, then at a rate of $3{ }^{\circ} \mathrm{min}^{-1}$ to $250{ }^{\circ} \mathrm{C}$; carrier gas hydrogen, $1.5 \mathrm{ml} \min ^{-1}\left(105{ }^{\circ} \mathrm{C}\right)$; injector split ratio $1: 15$ or splitless; injector temperature $250^{\circ} \mathrm{C}$, detector temperatur $260^{\circ} \mathrm{C}$. The quantitative evaluation referred to the internal standard using an electronic integrator (HP 3396).

GLC-MS: A Finnigan gas chromatograph 9610, directly coupled with a mass spectrometer (Finnigan 4021, Quadrupol), was used. Spectra were recorded at an electron energy of $70 \mathrm{eV}$ in combination with an Incos data system. The chromatographic conditions were identical, but carrier gas was helium at $1.2 \mathrm{ml} \cdot \mathrm{min}^{-1}\left(60{ }^{\circ} \mathrm{C}\right)$. Spectra were analyzed either by using reference compounds of the collection of the institute or by comparison with an internal NBS-library (ca. 36000 spectra).

All quantitative data originate from duplicate experiments using the same inoculum and are given as a mean value. If the deviation of the results was $>10 \%$, the experiment was repeated. Further subculturing did not significantly affect the quantitative data. None of the volatiles indicated in Table II was present in freshly prepared media.

\section{Results}

\section{Cell cultures}

The growth of photoheterotrophic calli of C.paradisi was slow and reached indices of 3 to 5 on the different media. The very firm aggregates had diameters of $<5 \mathrm{~cm}$. Photomixotrophic calli showed similar growth indices, but were softer, dark green, and formed smaller aggregates $(<1$ $\mathrm{cm}$ ). Conversion of photoheterotrophic calli to photomixotrophic ones did not result in chlorophyll formation, apart from MSL medium $(<15$ $\left.\mu \mathrm{g} \times \mathrm{g}^{-1}\right)$. Mixotrophic cells contained 7 to 9 wall associated chloroplasts, irrespective of the actual chlorophyll content. Thorough light microscopic investigation gave no hints on the presence of secretory cavities or idioblasts, oil blisters, trichomes or ducts, but showed a heterogeneous morphology with interspersed differentiation including tracheidal and red coloured cells with irregular, evaginated walls. Formation of rootlets or stems was not observed.
Primary callus of C.limon was observed after 4 weeks under heterotrophic and after 9 weeks under phototrophic conditions. The growth index of the soft heterotrophic cells was 9 to 10 , while firm, aggregating $(<4 \mathrm{~mm})$ phototrophic cells grew with an index of 6 to 7 . Conversion of heterotrophically initiated cells to the phototrophic state failed on all media. Phototrophic cells with different chlorophyll contents constantly contained 3 to 5 chloroplasts and sometimes fragments of tracheidal wall structures. No other cyto- or organ differentiation was found.

Flavedo explants of C.aurantifolia callused after 2 and 6 weeks under heterotrophic and phototrophic conditions, with growth indices of 9 to 10 and 5 to 6 , respectively. The heterotrophic cells were soft and crumbly, whereas the phototrophic ones were yellow-green to dark green and aggregated.

\section{Chemical analysis of constituents of C.paradisi}

Total chlorophyll and chlorophyll $a / b$ ratios reached stable values after five subcultivations of C.paradisi under 3,000 lux (Table I). Chlorophyll formation occurred in all illuminated cells on all nutrient media. A combination of the MSL medium, light colour 12, $24 \mathrm{~h}$ photoperiod and the twofold phytohormone concentrations as compared with the original medium yielded maximum amounts. As the calli grown on MSL medium exhibited a typical Citrus aroma, these cells were examined for their volatile composition.

\section{Volatiles in fruit and cultured cells of C.paradisi}

Citrus essential oils are complex mixtures of oligoisoprenoids and fatty acid degradation products. The sensory impression is determined by $(+)-4 R$ limonene, and quantity and ratio of side and trace components impart species character. Composition and yield of volatile constituents in C.paradisi cell cultures growing under different chemical and physical conditions were compared with the essential oil of the fruit of the plant. GLC-MS examination of the essential oil of C.paradisi reconfirmed the presence of 49 constituents, mainly monoterpenes, in the flavedo/albedo (exocarp) and edible (mesocarp/endocarp) portion of the fruit oil (Wilson and Shaw, 1987). Limonene, the precursor of the oxygenated p-menthane structures, accounted for $88 \%$ of the volatile fraction in the peel, fol- 
Table I. Chlorophyll accumulation $\left(\mathrm{mg} \times \mathrm{kg}^{-1}\right.$ fresh wt) in hetero- and photomixotrophically initiated callus of C.paradisi.

\begin{tabular}{|c|c|c|c|c|c|c|c|c|c|c|c|}
\hline \multirow{2}{*}{$\begin{array}{l}\text { Exp } \\
\text { no. }\end{array}$} & \multirow[t]{2}{*}{ Medium } & \multirow{2}{*}{$\begin{array}{l}\text { Light } \\
\text { colour }\end{array}$} & \multirow{2}{*}{$\begin{array}{l}\text { Photoperiod } \\
\text { light/dark(h) }\end{array}$} & \multirow{2}{*}{$\begin{array}{l}\text { Gellan gum } \\
\left(\mathrm{g} \times 1^{-1}\right)\end{array}$} & \multicolumn{5}{|c|}{ Phytoeffector ${ }^{\mathrm{a}}$ conc. $\left(\mathrm{mg} \times \mathrm{l}^{-1}\right)$} & \multirow[t]{2}{*}{ Chlorophyll } & \multirow[t]{2}{*}{ Chlorophyll $a / b$} \\
\hline & & & & & $2,4-\mathrm{D}$ & NAA & IAA & IBA & Kin & & \\
\hline \multicolumn{12}{|c|}{ heterotrophic } \\
\hline & $\mathrm{SH}^{\mathrm{b}}$ & HQL & $24 / 0$ & 3 & 0.5 & & & & & n.d. & - \\
\hline & $\mathrm{SH} 4$ & HQL & $24 / 0$ & 3 & & 0.5 & & & 2.0 & n.d. & - \\
\hline & $\mathrm{MS}^{\mathrm{c}}$ & HQL & $24 / 0$ & 3 & 1.0 & & & & 0.1 & n.d. & - \\
\hline & MSL & HQL & $24 / 0$ & 3 & & 0.25 & 1.0 & 0.5 & 0.25 & 15 & 1.4 \\
\hline \multicolumn{12}{|c|}{ photomixotrophic } \\
\hline & $\mathrm{SH}$ & HQL & $24 / 0$ & 3 & 0.5 & & & & & 35 & 1.4 \\
\hline & MS & HQL & $24 / 0$ & 3 & 1.0 & & & & 0.1 & 47 & 1.4 \\
\hline & SH4 & HQL & $24 / 0$ & 3 & & 0.5 & & & 2.0 & 73 & 1.5 \\
\hline 1 & MSL & HQL & $16 / 8$ & 3 & 0.25 & 1.0 & 0.5 & 0.25 & 142 & 1.9 & \\
\hline 2 & MSL & HQL & $24 / 0$ & 3 & & 0.25 & 1.0 & 0.5 & 0.25 & 180 & 1.9 \\
\hline 3 & MSL & 12 & $16 / 8$ & 3 & & 0.25 & 1.0 & 0.5 & 0.25 & 161 & 1.8 \\
\hline 4 & MSL & 12 & $24 / 0$ & 3 & & 0.25 & 1.0 & 0.5 & 0.25 & 193 & 2.0 \\
\hline 5 & MSL & 12 & $16 / 8$ & 3 & & 0.5 & 2.0 & 1.0 & 1.0 & 243 & 2.7 \\
\hline 6 & MSL & 12 & $24 / 0$ & 3 & & 0.5 & 2.0 & 1.0 & 1.0 & 310 & 2.9 \\
\hline 8 & MSL & HQL & $24 / 0$ & 9 & & 0.25 & 1.0 & 0.5 & 0.25 & 183 & 2.2 \\
\hline 9 & MSL & 12 & $24 / 0$ & 9 & & 0.5 & 2.0 & 1.0 & 1.0 & 212 & 2.5 \\
\hline
\end{tabular}

a 2,4-dichlorophenoxyacetic acid; naphthylacetic acid; indoleacetic acid; indolebutanoic acid; kinetin.

b $\mathrm{SH}$ medium additionally contains p-chlorophenoxyacetic acid $\left(2.0 \mathrm{mg} \times \mathrm{l}^{-1}\right)$.

c MS medium additionally contains 6-benzylaminopurine $\left(0.1 \mathrm{mg} \times \mathrm{l}^{-1}\right)$.

lowed by myrcene $(2 \%)$, n-octanal $(2 \%)$ and citronellal $(1 \%)$. (2E)-hexenal and nootkatone dominated in the fleshy part. When callus was grown under the conditions of experiment No. 4 (Table I), the extracted volatiles comprised thirtyeight compounds. Chemical structures and quantitative composition were very similar to cold pressed grapefruit peel oil (Table II). All components extracted from the cell culture were also found in the peel oil, except tri- and tetradecanal. Some trace constituents of the peel were not found in the cell culture, probably as a result of a lack of analytical sensitivity. Experiment No. 6 (Tables I and II) resulted in maximum formation of limonene and total volatiles, but at the expense of the diversity of the chemical composition. These accumulations represent de novo synthesis, because

- carry-over from the primary callus that contained only traces of volatiles was negligible,

- pattern and quantity of volatiles reproducibly depended on the subcultivation conditions chosen and changed upon variation of the nutrients, and - accumulation dropped to zero in suspension cultures and was restored on subsequent transfer to solidified medium.

Fig. 1 shows distinct quantitative differences in extracts of the tissues from the intact plant and of

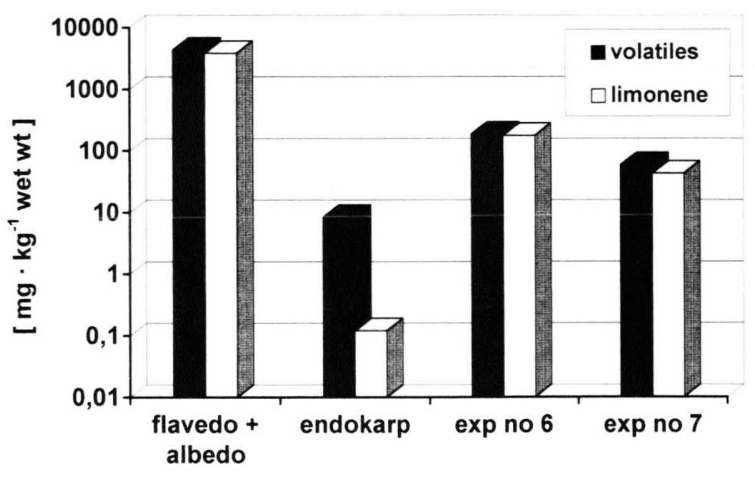

Fig. 1. Total volatiles and limonene in differentiated tissues and photomixotrophic callus of C.paradisi.

the best yielding photomixotrophic callus culture: The cell culture contained about $5 \%\left(186 \mathrm{mg} \times \mathrm{kg}^{-1}\right.$ wet wt) of the volatiles found in peel tissue (exo/ mesocarp section), and about the twentyfold amount of that found in the fleshy endocarp. The direct comparison of the aroma producing potentials of differentiated plant part and cell culture is complicated by the heterogenous morphology and concentration gradients of the fruit. If the whole fruit is regarded as a source of aroma, the wet weight based figures of differentiated tissue and cell culture are in the same order of magnitude $(0.029$ vs. $0.019 \% \mathrm{w} / \mathrm{w})$; however, on a time base. 
Table II. Volatiles in photomixotrophic callus of C.paradisi (conds see Table I).

\begin{tabular}{|c|c|c|c|}
\hline Constituent & $\begin{array}{l}\text { Experiment } \\
\text { No. } 4 \\
\quad(\mathrm{mg} \times \mathrm{k}\end{array}$ & $\begin{array}{l}\text { Experiment } \\
\text { No. } 6 \\
\text { fresh wt) }\end{array}$ & $\begin{array}{l}\text { Method of } \\
\text { identification }\end{array}$ \\
\hline$\alpha$-Pinene & 0.09 & 0.58 & MS, RT \\
\hline$\beta$-Pinene & trace & trace & MS, RT \\
\hline Sabinene & 0.22 & 0.67 & MS, RT \\
\hline Myrcene & 0.74 & 3.75 & MS, RT \\
\hline (+)-Limonene & 48.35 & 176.73 & MS, RT \\
\hline$(E)$ - $\beta$-Ocimene & 0.06 & 0.28 & MS, RT \\
\hline n-Octanal & 1.17 & 0.41 & MS, RT \\
\hline (3Z)-Hexenal & 0.11 & & MS \\
\hline$n$-Nonanal & 0.41 & & MS, RT \\
\hline $\begin{array}{l}\text { Limonen-1,2- } \\
\text { epoxide }\end{array}$ & 0.02 & & MS \\
\hline$(Z)$-Linalool oxide & 0.02 & & MS \\
\hline$\alpha$-Pinene oxide & 0.05 & & MS \\
\hline $\begin{array}{l}(E) \text {-Sabinene } \\
\text { hydrate }\end{array}$ & 0.20 & 0.32 & MS, RT \\
\hline Citronellal & 0.95 & 0.59 & MS, RT \\
\hline$\alpha$-Copaene & 0.02 & 0.16 & MS \\
\hline$n$-Decanal & 0.35 & 0.23 & MS, RT \\
\hline Linalool & 0.07 & 0.16 & MS, RT \\
\hline$n$-Octanol & 0.08 & 0.65 & MS, RT \\
\hline$\beta$-Caryophyllene & 0.19 & & MS, RT \\
\hline Terpinen-4-ol & 0.24 & & MS, RT \\
\hline $\begin{array}{l}\text { (E)-2,8-p-Mentha- } \\
\text { dien-1-ol }\end{array}$ & 0.03 & & MS, RT \\
\hline$\alpha$-Humulene & & 0.08 & MS, RT \\
\hline Neral & 0.24 & 0.15 & MS, RT \\
\hline (E)-Piperitol & 0.04 & 0.17 & MS \\
\hline$\alpha$-Terpineol & 0.22 & 0.27 & MS, RT \\
\hline$n$-Dodecanal & 0.76 & 0.17 & MS, RT \\
\hline Geranial & 0.29 & 0.17 & MS; RT \\
\hline$\delta$-Cadinene & & 0.19 & MS; RT \\
\hline Geranyl acetate & 0.03 & 0.16 & MS; RT \\
\hline Perillaldehyd & 0.05 & & MS \\
\hline Nerol & 0.03 & & MS; RT \\
\hline$n$-Tridecanal & 0.20 & & MS; RT \\
\hline$(E)$-Carveol & 0.03 & & MS; RT \\
\hline Geraniol & 0.04 & & MS; RT \\
\hline$n$-Tetradecanal & 0.20 & & MS; RT \\
\hline Nerolidol & 0.06 & & MS; RT \\
\hline Nootkatone & 0.30 & 0.64 & MS, RT \\
\hline
\end{tabular}

the productivity of the cultured cells is superior (13 months from anthesis to mature fruit vs. 4 weeks of subcultivation). Permanent illumination instead of a $16 / 8$ hours photoperiod stimulated the formation of volatiles, as did the use of light colour 12 neon tubes. A $50 \%$ increase of total auxin and kinetin concentrations was lethal.

Changed conditions of cultivation also affected the pattern of volatiles (Fig. 2). Experiments No. 1 to 6 resulted in essential oils with a composition that closely resembled that of peel oil. Increased concentration of the gelling agent in experiments No. 7 to 9 reduced the diffusion of nutrients into the cells and the secretion of volatiles into the medium. In turn, the saturated aldehydes from six

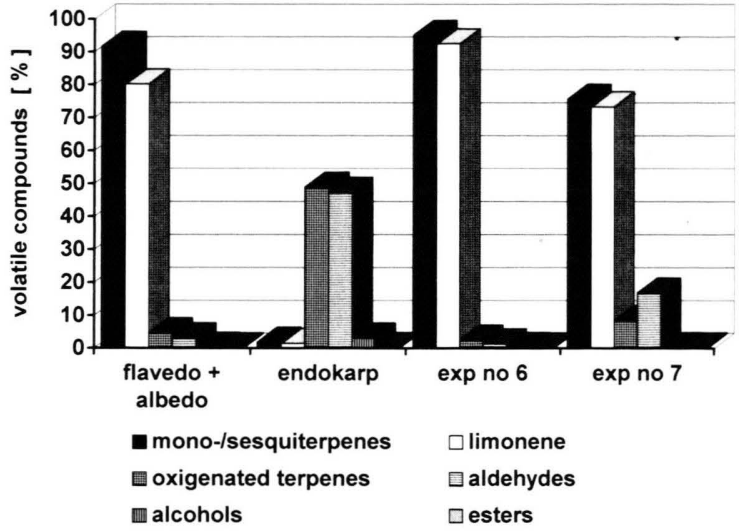

Fig. 2. Composition of essential oils in differentiated tissues and photomixotrophic callus cultures of C.paradisi.

to fourteen carbons increased. In contrast to fruit essential oil, limonene remained the major compound in these cell cultures. Formation of volatiles was not observed in any of the heterotrophically initiated cells nor in phototrophic cells that contained less than $140 \mathrm{mg}$ chlorophyll per $\mathrm{kg}$.

A linear regression curve resulted from the correlation of the contents of total volatiles and chlorophyll, as obtained from experiments no. 1 to 9 (Fig. 3). Smaller amounts $(<10 \%)$ of volatiles leaked into the surrounding agar zones, but were not included into these calculations. The worser fit of the regression line for experiments no. 5 and 6 may be interpreted as a declining slope passing over to a saturation curve-type behaviour; however, a further systematic approach to improve terpene yields was not in the scope of this work. Production of aroma compounds has been observed for more than 2 years of continued sub-culturing.

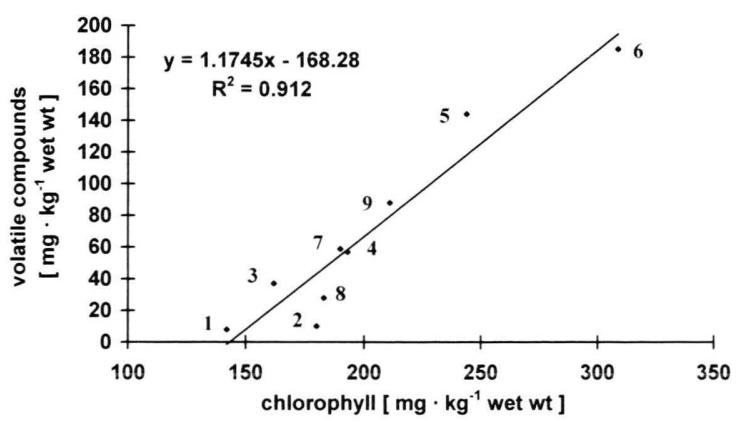

Fig. 3. Chlorophyll vs, total volatiles in photomixotrophic callus cultures of C.paradisi. 
Incubation of suspended, stationary phase cells with exogenous valencene led to the intermediary formation of the 2-hydroxy-derivative, followed by conversion to the 2-oxo-compound, nootkatone ( $68 \%$ in $24 \mathrm{~h}$ ). The once reached concentration of nootkatone (ca. $0.7 \mathrm{mg} \times \mathrm{l}^{-1}$ ) was maintained for another $48 \mathrm{~h}$ without noticable change. Then the experiment was terminated. The competing chemical oxidation was not measurable under conditions.

\section{Volatiles in fruit and cultured cells of C.limon}

The same chemical and light conditions that favoured terpene formation in C.paradisi cells were successful for C.limon (Table III). Because of the about fivefold lower actual concentrations, only 12 volatiles were identified, among them acyclic, mono-, and bicyclic monoterpene hydrocarbons and oxygenated derivatives. Limonene was again the major volatile, and a fairly constant ratio of limonene $/ \beta$-pinene of $5.0 \pm 0.4$ was found. According to Bauer and Garbe (1985), cold pressed lemon oil is composed of $65 \%$ limonene, 8 to $10 \%$ $\beta$-pinene, 8 to $10 \% \gamma$-terpinene, and 3 to $10 \%$ ne$\mathrm{ral} /$ geranial (= citral, the character impact component). A comparison with the concentration of volatiles accumulated by the cell cultures (Table III) shows that the lipophilic extracts equal the reported composition of lemon essential oil. The yields were again positively affected by continuous light, light colour 12, and by elevated concentrations of gelling agent and phytoeffectors.

Other analogies between C.limon and C.paradisi were the correlation of chlorophyll and terpene contents (Fig. 4) and the complete absence of volatiles in suspension cultures. When suspended, light grown cells were transferred back onto solid medium, the capability to form volatiles was fully restored after 3 subcultivations.

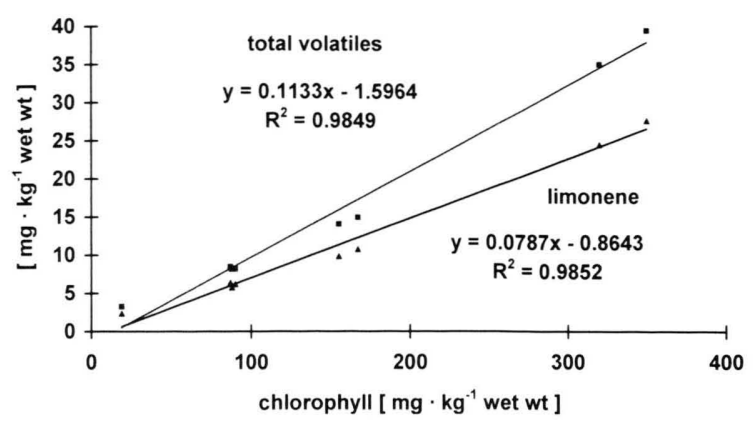

Fig. 4. As in Fig. 3 for C.limon; top line: total volatiles, lower line: limonene.

\section{Volatiles in cultured cells of C.aurantifolia}

Duplicating the experimental conditions as given in Table III, the experiments were repeated with lime cells (Fig. 5). A significantly faster growth was associated with an eightfold lower actual accumulation of volatiles as compared to C.limon. Limonene was the only volatile identified. Chlorophyll and limonene formation were again closely correlated, and the same qualitative relation of cultivation conditions and chlorophyll/ limonene accumulation was found. The course of the regression curve fitted best with a typical exponential saturation curve; this difference may be attributed to the lower over-all productivity. A maximum of $390 \mathrm{mg}$ chlorophyll and of $4.4 \mathrm{mg}$

Table III. Accumulation of chlorophyll $\left(\mathrm{mg} \times \mathrm{kg}^{-1}\right.$ fresh wt) and volatiles $\left(\mu \mathrm{g} \times 100 \mathrm{~g}^{-1}\right.$ fresh wt) in photomixotrophically initiated callus of C.limon (MSL medium, 3,000 lx continuous light, 4 weeks subcultivated).

\begin{tabular}{|c|c|c|c|c|c|c|c|c|c|c|}
\hline \multirow{2}{*}{$\begin{array}{l}\text { Exp } \\
\text { No. }\end{array}$} & \multirow{2}{*}{$\begin{array}{l}\text { Light } \\
\text { color }\end{array}$} & \multirow{2}{*}{$\begin{array}{l}\text { Gellan gum } \\
\left(\mathrm{g} \times \mathrm{1}^{-1}\right)\end{array}$} & \multicolumn{4}{|c|}{ Phytoeffector $^{\mathrm{a}}\left(\mathrm{mg} \times \mathrm{l}^{-1}\right)$} & \multirow[t]{2}{*}{ Chlorophyll } & \multirow[t]{2}{*}{$\beta$-Pinene } & \multirow[t]{2}{*}{ Limonene } & \multirow{2}{*}{$\begin{array}{l}\text { Total } \\
\text { volatiles }\end{array}$} \\
\hline & & & NAA & IAA & IBA & Kin & & & & \\
\hline 1 & $\mathrm{HQL}$ & 3 & 0.25 & 1.0 & 0.5 & 0.25 & 19 & 49 & 234 & 326 \\
\hline 3 & HQL & 9 & 0.25 & 1.0 & 0.5 & 0.25 & 90 & 114 & 617 & 817 \\
\hline 4 & HQL & 9 & 0.5 & 2.0 & 1.0 & 1.0 & 87 & 114 & 637 & 846 \\
\hline 5 & 12 & 3 & 0.25 & 1.0 & 0.5 & 0.25 & 155 & 204 & 983 & 1,409 \\
\hline 6 & 12 & 3 & 0.5 & 2.0 & 1.0 & 1.0 & 167 & 222 & 1,075 & 1,497 \\
\hline 7 & 12 & 9 & 0.25 & 1.0 & 0.5 & 0.25 & 320 & 505 & 2,460 & 3.510 \\
\hline 8 & 12 & 9 & 0.5 & 2.0 & 1.0 & 1.0 & 350 & 602 & 2,776 & 3,958 \\
\hline
\end{tabular}

a see Table I. 


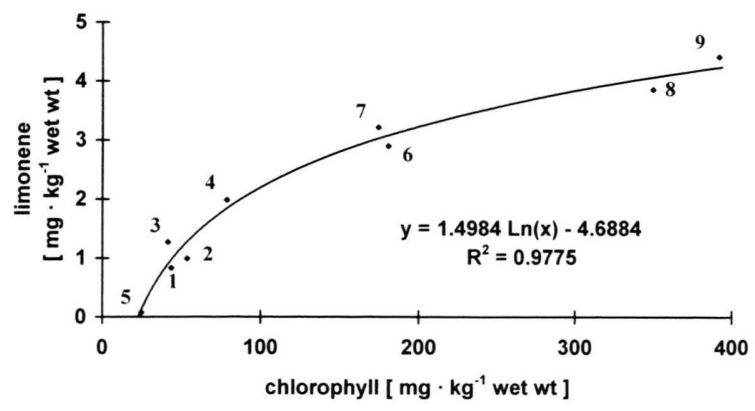

Fig. 5. Chlorophyll vs. limonene in photomixotrophic callus cultures of C.aurantifolia.

limonene per $\mathrm{kg}$ wet weight, respectively, was reached using the conditions No. 8 of Table III (exp. No. 9 in Fig. 5).

\section{Discussion}

\section{The effect of light}

Lower oligoprenoids are important as insect repellents, antifeedants and as chemical messengers in ecological interactions in general. Many observations with cultures of essential oil plants indicated, however, that cells in a sterile and confined environment produce only very low amounts of terpenoids or lose accumulation completely. Various attempts to overcome this situation included improving the availability of the early precursor by feeding mevalonate (Nabeta et al., 1993), lowering the cultivation temperature (Chae and Park, 1994), and changing the nutrient composition (Agrawal et al., 1991).

Both the quality and quantity of light affect the synthesis of terpenes in intact plants by regulating the key enzyme 3-hydroxy-3-methylglutaryl-CoA reductase (Stermer et al., 1994). The photoperiod received by leaves of Mentha piperita directly influenced the oil composition (Voirin et al., 1990). Similarly, the level of terpene accumulation was linked to the photonic fluence in Ginkgo biloba leaves (Flesch et al., 1992). An increase in the levels of chloroplast isopentenyl diphosphate (IDP) isomerase during light-stimulated carotenoid biosynthesis in maize has been observed (Albrecht and Sandmann, 1994).

Analogous reports on cell cultures referred to the formation of root-like volatiles in heterotrophic and leaf-like volatiles in photomixotrophic suspension cells of Ruta graveolens (Jordan et al., 1986), and the formation of leaf-like terpenoids in photomixotrophic callus of Coleonema album (Berger et al., 1990). In geranium cultures, a stimulation in the accumulation of essential oil of some 200-fold was induced by a transfer into a long-light photoperiod (Charlwood et al., 1989). Callus of cotton lavender contained himachalene-type sesquiterpenes when grown under continuous illumination of 600 lux (Banthorpe, 1994). Calli of hop (Banthorpe et al., 1989) and Japanese larch (Nabeta, 1994) were grown under continuous light of 600 and 5,000 lux, respectively, and converted mevalonate precursors into volatile sesquiterpenes. The concentration of a precursor of the norisoprenoid $\beta$-damascenone in Concord grape callus was raised by light (Shure and Acree, 1994). Electron microscopy of dark grown, valencene and nootkatone producing grapefruit cells revealed that plastids were present, possibly from the light grown preculture (Del Rio and Ortuño, 1994).

Many of the earlier authors did not emphasize the role of light. As a result, light conditions were not changed systematically, and dark grown cells were not compared or not even mentioned, because the respective experiments were regarded „unsuccessful“. The data obtained with callus cells of Citrus show that the phototrophic state was indispensible for the generation of monoterpenes, and that secondary parameters affected composition and yield. As in most of the studies cited above, suspended cells were inferior in terms of volatile accumulation, and levels of volatiles in the callus did rarely exceed $5 \%$ of that found in a specialized tissue of the parent plant.

\section{Plastidic development and terpene formation}

The close correlation of chlorophyll and monoterpene accumulation in Citrus cells was not found in partially differentiated cultures of Tanacetum vulgare (Banthorpe and Wirz-Justice, 1972). When the synthesis of chlorophyll was inhibited these cells still accumulated the same monoterpenes in similar yields to the green cells. It was therefore concluded that monoterpene synthesis was independent of the presence of functional chloroplasts. This apparent contradiction may be solved looking again at intact essential oil plants: Non-photosyn- 
thetic secretory cells from glandular trichomes of peppermint were used to demonstrate that the IDP utilized for both monoterpene and sesquiterpene biosynthesis is formed exclusively in leucoplasts which contain all of the enzymes necessary to produce monoterpenes from an exogenous carbon source such as sucrose (McCaskill et al., 1992); intact leucoplasts from Citrofortunella mitis converted exogenous IDP into monoterpene hydrocarbons (Gleizes et al., 1987), but only intact chromoplasts achieved the full synthetic potential in the absence of exogenous dimethylallyl diphosphate, the reactive primer molecule (Mettal et al., 1988). This provides evidence that plastids are the subcellular compartment of formation of monoterpenes and diterpenes. Geranyl and geranylgeranyl diphosphate synthases have both been localized in this organelle (Soler et al., 1992; Cheniclet et al., 1992). Oxygenation then takes place at the endoplasmatic reticulum.

Farnesyl diphosphate synthase and the subsequent steps towards the synthesis of sesquiterpenes and triterpenes are localized in the cytoplasm and endoplasmic reticulum. Therefore, IDP formation must proceed along parallel pathways, while the further metabolic fate can change according to developmental requirements. The callus cultures of Citrus obviously maintained the physiological state of the tissue from which they were derived (Tables II and III), because both fruit (endocarp) and leaf essential oils show a different composition. A (-)- $4 S$-limonene synthase was purified from spearmint, the corresponding cDNA has been isolated, sequenced and the catalytically active enzyme expressed in E. coli (Colby et al., 1993). The recombinant limonene cyclase preprotein was catalytically active, producing about the same spectrum and proportions of monoterpene hydrocarbons as the C.paradisi callus enzyme (Table II). Though 3 non-identified sesquiterpenes were omitted from Table II, this class of oligoprenoids is, as in peel oil, not well represented in callus extracts. The cytoplasmic sesquiterpene pathway appears to compete poorly for the available IDP relative to the plastidic monoterpene pathway.

\section{Role of phytoeffectors}

Phytoeffectors may in some way affect or interact with the processes by which light controls gene expression. Illuminated callus of Cnidium officinale produced more volatiles in the presence of naphthylacetic acid (NAA) than 2,4-dichlorophenoxyacetic acid (2,4-D)(Shin and Park, 1994). Similarly, NAA and indoleacetic acid (IAA) promoted the formation of thymol and chlorophyll in calli of Carum copticum, while 2,4-D resulted in unorganized proliferation (Prabha et al., 1991). Substitution of 2,4-D and $p$-chlorophenoxyacetic acid by a lower amount of NAA and high kinetin concentrations favoured the formation of essential oil in Coleonema album (Berger et al., 1990). The present study achieved maximum product formation by using rather high dosages of a mixture of NAA, IAA, and indolebutanoic acid (Tables I and III).

Application of phytoeffectors may lead to differentiation, organogenesis, and, ultimately, to regenerated plantlets that usually produce the same essential oil as the parent plant (Abou-Mandour et al., 1994; Gozu et al., 1993; Segura and Calvo, 1991)). It was concluded that some degree of specialization must be present in order for both synthesis and accumulation of oligoprenoids to be observed. However, geranium cell lines derived from the same inoculum differed in oil content, but not in morphology indicating that the regulation of these two characters is not linked (Charlwood et al., 1989). In the present study, the number of chloroplasts per cell remained constant under different light and phytoeffector regimes, while concentrations of chlorophyll and terpenes changed. It is supposed that plastid differentiation, i.e. formation and orientation of enzymes and possibly transporters, but not cytodifferentiation or organogenesis is crucial.

\section{Toxicity of oligoisoprenoids}

Higher plants excrete mono- and sesquiterpenes into specialized storage sites, such as glandular hairs, lipid vesicles,or resin ducts. In tissue cultures that do not contain an appropriate metabolic sink, essential oil components may severely disturb respiration, photosynthesis, and membrane functions. The toxicity of some monoterpenes to growning cell cultures was determined (Brown et al., 1987). As was estimated accordingly, suspended cells would withstand $<100 \mathrm{mg}$ of certain monoterpenoids per $\mathrm{L}$ of medium before toxicity would occur. 
More than $1 \mathrm{mg} \beta$-damascenone per 1 (about $5 \mu \mathrm{m}$ ) was toxic to suspended grape cells (Shure and Acree, 1995). Valencene concentrations $>1 \mathrm{mg}$ per 1 resulted in decreased conversion capacity of C.paradisi (Drawert et al., 1984). The strategy of cultured cells to deal with exogenous, toxic terpenes is rapid degradation, a process so prominent that cultured cells have been used for characterizing catabolic pathways (Funk and Croteau, 1993; Berger et al., 1990a). Endogenous accumulation may induce the same catabolic sequences to prevent autotoxicity.

In contrast to earlier results obtained with heterotrophic cultures of many different species, the C.paradisi cells accumulated significant amounts of intracellular oligoprenoids (Fig. 1). Though growth rates and oligoprenoid formation were inversely related in all of the experiments shown, only the C.aurantifolia cells appeared to reach a saturation level (Fig. 5), while the linearity of the curves in Fig.s 3 and 4 suggests that a further increase of volatiles could occur. The physiological state of photomixotrophic cells may contribute to an improved tolerance to oligoprenoids.

Abou-Mandour A. A., van den Berg T. and Czygan F.C. (1994), Regeneration of plants and production of volatiles from callus cultures of Melissa officinalis L. Angew. Bot. 86, 163-167.

Agrawal R., Patwardhan M. V. and Gurudutt K. N. (1991), Formation of flavouring constituents in callus cultures of lime, Citrus aurantifolia S. Biotech. Appl. Biochem. 14, 265-274.

Albrecht M. and Sandmann G. (1994), Light-stimulated carotenoid biosynthesis during transformation of maize etioplasts is regulated by increased activity of isopentenyl pyrophosphate isomerase. Plant Physiol 105, 529-534.

Banthorpe D. V. (1994) Santolina chamaecyparissus L. (Cotton Lavender): In vitro culture and the production of lower terpenoids. In: Biotechnology in Agriculture and Forestry, 28 (Y. P. S. Bayay, ed.). Springer Berlin, Heidelberg, pp. 412-425.

Banthorpe D. V. and Wirz-Justice A. (1972), Monoterpenes and carotenoids from tissue cultures of Tanacetum vulgare L. JCS Perkin 1, 1769-1772.

Banthorpe D. V., Brown J. T. and Morris G. S. (1989), Production of trans- $\beta$-farnesene by callus of Humulus lupulus. Phytochemistry 28, 1847-1849.

Bauer K. and Garbe D. (1985) Common Fragrance and Flavor Materials. VCh Weinheim.
A second aspect may be a reduced access to or activity of endogenous degrading enzymes. This view is supported by the lower tolerance towards exogenous valencene of heterotrophic suspension cultures of Citrus (Drawert et al., 1984). These cells reached the maximum nootkatone concentration after $6 \mathrm{~h}$ and degraded substrate and product almost completely within $24 \mathrm{~h}$. A remarkably high tolerance towards the monoterpenoid precursor $\Delta^{2}$-carene and stable accumulation of transformation products has also been reported for illuminated callus cells of Myrtillocactus geometrizans (Gil et al., 1994).

\section{Acknowledgements}

This work was supported by the Federal Minister of Research and Technology (project no. 0318980A) and by the Fonds der Chemischen Industrie. Valuable advice came from the members of the project group. S. Pilawa and B. Zimmermann are thanked for analytical and technical collaboration.

Berger R.G., Akkan Z. and Drawert F. (1990), The essential oil of Coleonéma album (Rutaceae) and of a photomixotrophic culture derived thereof. Z. Naturforsch. 45c, $187-195$.

Berger R.G., Akkan Z. and Drawert F. (1990a), Catabolism of geraniol by suspension cultured C.limon cv. Ponderosa. Biochim. Biophys. Acta 1055, 234-239.

Bricout J. and Paupardin C. (1974), Sur la composition de l'huile essentielle de tissue de péricarpe de citron. C. R. Acad. Sci. Paris Ser. D 278, 719-722.

Brown J.T., Hegarty P.K. and Charlwood B.V. (1987), The toxicity of monoterpenes to plant cell cultures. Plant Sci. 48, 195-201.

Chae, Y. A. and Park S. U. (1994), Effects of subculture and cold temperature on the oil content and menthol synthetic ability in the callus cells of Mentha piperita L. Breed. Res. Biotechnol. Vol. 2, 515-521.

Charlwood B. V., Moustou C., Brown J. T., Hegarty P. K. and Charlwood K. A. (1989), The regulation of accumulation of lower isoprenoids in plant cell cultures. In: Primary and Secondary Metabolism in Plant Cell Cultures (W. G. W. Kurz, ed.). Springer Berlin, Heidelberg, pp. 73-84. 
Cheniclet C., Rafia F. Saint-Guily A., Verna A. and Carde J.-P. (1992), Localization of the enzyme geranylgeranylpyrophosphate synthase in Capsicum fruits by immunogold cytochemistry after conventional chemical fixation or quick-freezing followed by freeze-substitution. Labelling evolution during fruit ripening. Biol. Cell 75, 145-150.

Colby S.M., Alonso W.R., Katahira E.J., McGarvey D.J. and Croteau R. (1993), 4-S-Limonene synthase from the oil glands of spearmint (Mentha spicata): cDNA isolation, characterization, and bacterial expression of the catalytically active monoterpene cyclase. J. Biol. Chem. 268, 23016-23026.

Del Rio J.A. and Ortuño A. (1994), Citrus paradisi Macf. (Grapefruit): In vitro culture and the bioproduction of sesquiterpenes nootkatone, valencene, and other secondary metabolites. In: Biotechnology in Agriculture and Forestry, 28 (Y. P. S. Bayay, ed.). Springer Berlin, Heidelberg, pp. 123-138.

Drawert F. and Berger R. G. (1982), Biosynthese von Aromastoffen in Segment-, Kallus- und Suspensionskulturen von Citrusarten. Chem. Mikrobiol. Technol. Lebensm. 7, 143-147.

Drawert F., Berger R. G. and Godelmann R. (1984), Regioselective biotransformation of valencene in cell suspension cultures of Citrus. Plant Cell Rep. 3, $37-$ 40.

Flesch V., Jacques M., Cosson L., Teng B. P., Petiard V. and Balz J. P. (1992), Relative importance of growth and light level on terpene content of Ginkgo biloba. Phytochemistry 31, 1941-1945.

Funk C. and Croteau R. (1993), Induction and characterization of a cytochrome P-450-dependent camphor hydroxylase in tissue cultures of common sage (Salvia officinalis). Plant Physiol. 101, 1231.

Gil G., Ferreira dos Santos P. and Bullard C. (1994), Biotransformation of $\Delta^{2}-$ carene by callus tissues. Phytochemistry 38, 629-631.

Gleizes M., Camara B. and Walter J. (1987), Some characteristics of terpenoid biosynthesis by leucoplasts of Citrofortunella mitis. Planta 170, 138-140.

Gozu Y., Yokoyama M., Nakamura M., Namba R., Yomogida K., Yanagi M. and Nakamura S. (1993), In vitro propagation of Iris pallida. Plant Cell Rep. 13, $12-16$.

Jordan M., Rolfs C. H., Barz W., Berger R. G., Kollmannsberger H. and Drawert F. (1986), Characterization of volatile constituents from heterotrophic cell suspension cultures of Ruta graveolens. Z. Naturforsch. 41c, 809-812.

McCaskill D., Gershenzon J. and Croteau R. (1992), Morphology and monoterpene biosynthesis of secretory cell clusters isolated from glandular trichomes of peppermint (Mentha piperita L.). Planta 187, 445.

Mettal U., Boland W., Beyer P. and Kleinig H. (1988), Biosynthesis of monoterpene hydrocarbons by isolated chromoplasts from daffodil flowers. Eur. J. Biochem. 170, 613-616.
Murashige T. and Skoog F. (1962), A revised medium for rapid growth and bioassays with tobacco tissue cultures. Physiol. Plant. 15, $473-481$.

Nabeta K. (1994), Larix leptolepis (Japanese Larch): In vitro culture and the production of secondary metabolites. In: Biotechnology in Agriculture and Forestry 28 (Y. P. S. Bayay, ed.). Springer Berlin, Heidelberg, pp. $271-288$.

Nabeta K., Kawachi J. and Sakurai M. (1993), Volatile production in cultured cells and plantlet regeneration from protoplast of patchouli, Pogostemon cablin. Dev. Food Sci. 32, 577-589.

Paupardin C. (1974), Sur I'evolution de l'huile essentielle dans des tissus de fruits de citron (Citrus limonia Osbeck) cultivés in vitro dans diverses conditions. Rev. Gen. Bot. 81, 223-241.

Prabha T. N., Agrawal R., Ramasharma P. R. and Patwardhan M. V. (1991), Intermediary metabolism and thymol formation in in vitro cultures of Carum copticum. Biotech. Appl. Biochem. 14, 256-264.

Schenk R. H. and Hildebrandt A. C. (1972), Medium and techniques for induction and growth of monocotyledonous and dicotyledonous plant cell cultures. Can. J. Bot. 50, 199-209.

Segura J. and Calvo C. M. (1991), Lavandula sp. (Lavender): In vitro culture, regeneration of plants, and the formation of essential oils and pigments. In: Biotechnology in Agriculture and Forestry, 15 (Y. P. S. Bayay, ed.). Springer Berlin, Heidelberg, pp. 283-288.

Shin S.-W. and Park B. (1994), The production of essential oils by tissue culture of Cnidium officinale. Yakhak Hoechi 38, 179-183, from CA 122: 235312.

Shure K. B. and Acree T. E. (1994), Production of $\beta$ damascenone precursors in cell cultures of Vitis lambrusca cv. Concord grapes. Plant Cell Rep. 13, 477480.

Shure K. B. and Acree T. E. (1995), Partial characterization of $\beta$-damascenone precursors and toxicity studies of free $\beta$-damascenone in cell cultures of Vitis lambrusca cv. Concord grapes. Dev. Food Sci 37B, 1645.

Soler E., Feron G., Clastre M., Dargent R., Gleizes M. and Ambid C. (1992), Evidence for a geranyl-diphosphate synthase located within the plastids of Vitis vinifera $\mathrm{L}$. cultured in vitro. Planta 187, 171.

Stermer B.A., Bianchini G.M. and Korth K.L. (1994), Regulation of HMG-CoA reductase in plants. J. Lipid Res. 35, 1133.

Voirin B., Brun N. and Bayet C. (1990), Effects of daylength on the monoterpene composition of leaves of Mentha piperita. Phytochemistry 29, 749-755.

Wilson C. W. and Shaw P. E. (1987), Quantitative composition of cold-pressed grapefruit oil. J. Agric. Food Chem. 26, $1432-1434$.

Ziegler R. and Egle K. (1965), Zur quantitativen Analyse der Chloroplastenpigmente. Beitr. Biol. Pfl. 41. $11-19$. 